International Journal of Health Sciences
Available online at www.sciencescholar.us
Vol. 6 No. 1, April 2022, pages: 187-195
e-ISSN: 2550-696X, p-ISSN: 2550-6978
https://doi.org/10.53730/ijhs.v6n1.3711

\title{
Distance Learning Development in COVID-19 Context
}

\begin{tabular}{|c|c|}
\hline \multicolumn{2}{|c|}{$\begin{array}{l}\text { Oksana Voitovska a , Kaleriia Kovalova }{ }^{\text {b }} \text {, Viktoriia Kuleshova c, Oksana Kravchuk d }{ }^{\text {, }} \text { Olena Moroz } \\
\text { Manuscript submitted: } 7 \text { September 2021, Manuscript revised: } 20 \text { December 2021, Accepted for publication: 6 January } 2021 \\
\end{array}$} \\
\hline Corresponding Author ${ }^{\text {a }}$ & Abstract \\
\hline $\begin{array}{l}\text { Keywords } \\
\text { COVID-19; } \\
\text { distance education; } \\
\text { distance learning; } \\
\text { higher education; } \\
\text { mental health; }\end{array}$ & $\begin{array}{l}\text { The purpose of the article is to evaluate the practice and experience in the } \\
\text { development of distance learning forms. Methodology. This article used } \\
\text { secondary data from the UK Student Survey (Office of National Statistic COVID- } \\
19 \text { Insights Survey (SCIS) during May } 4-12 \text { and November 19-29, 2021, to } \\
\text { assess trends in the impact of the pandemic on their success. Results. The study } \\
\text { found that limitations in higher education due to the spread of the coronavirus } \\
\text { have driven the need for online education. In the UK, the most common } \\
\text { education form was self-study or distance learning with a lecturer. Its } \\
\text { prevalence has decreased as restrictions continue due to the online learning } \\
\text { forms development (from } 14 \% \text { to } 55 \% \text { ). With the developments, the number of } \\
\text { students wishing to continue learning may be related to the adaptation to the } \\
\text { new educational environment. In the UK, the combination of different distance } \\
\text { learning methods is also changing, and the availability of online materials is } \\
\text { increasing. The reduction in the amount of students' group work, the number of } \\
\text { pre-recorded lectures or content, and the number of scheduled online classes } \\
\text { from } 76 \% \text { to } 40 \% \text { remains negative. }\end{array}$ \\
\hline
\end{tabular}

International Journal of Health Sciences (C) 2022. This is an open access article under the CC BY-NC-ND license (https://creativecommons.org/licenses/by-nc-nd/4.0/).

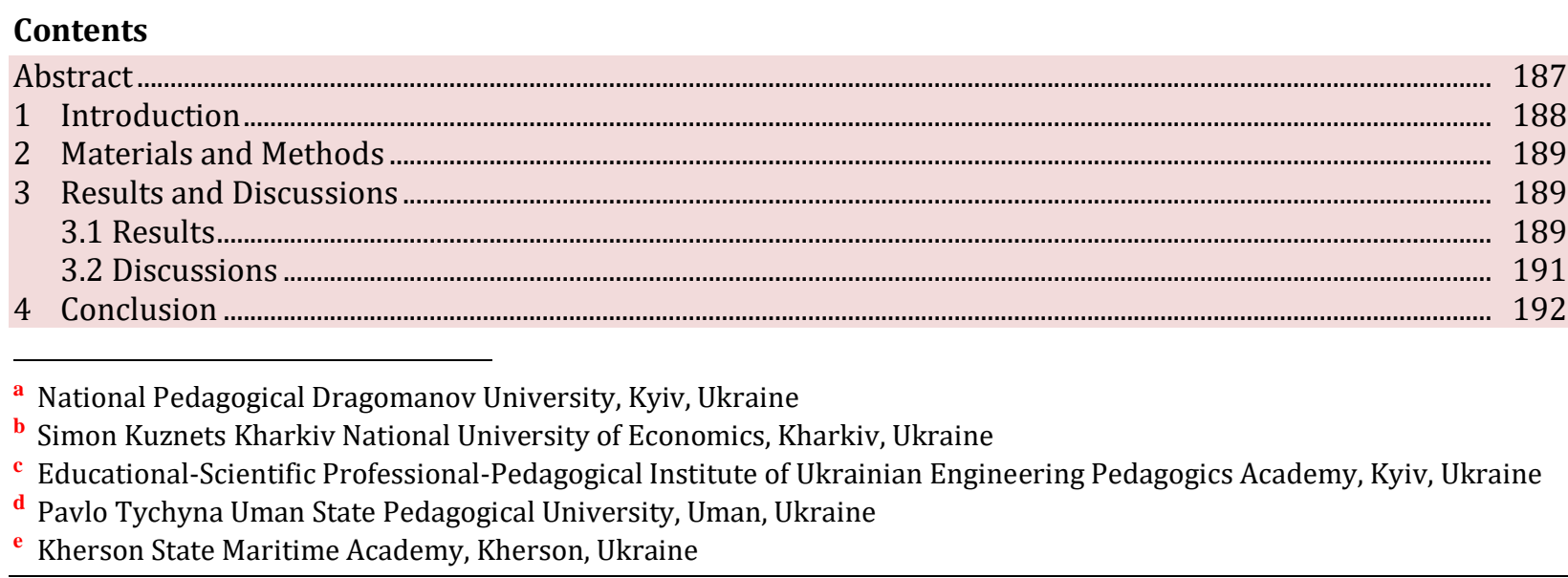




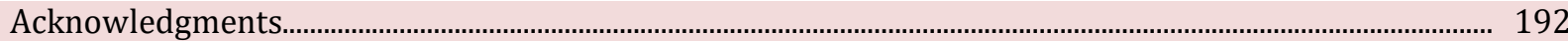

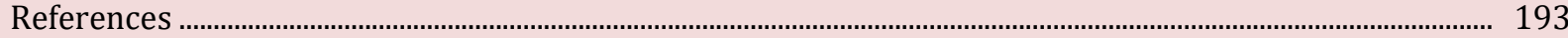

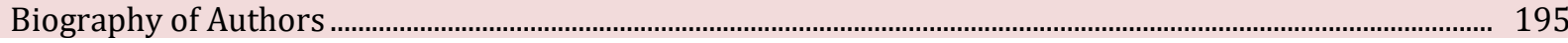

\section{Introduction}

The Coronavirus (SARS-CoV-2) pandemic required significant changes in higher education organizations, new strategies, and teaching methods to ensure student achievements. Distance or online learning is becoming the norm in the new educational environment (Lytvyn et al., 2021). Higher education institutions are addressing the challenges of an active transition to a digital learning environment and a renewed digital infrastructure (Schneider \& Council, 2021). The use of digital tools in education is increasing significantly during the crisis (Goudeau et al., 2021). According to UNESCO, unprecedented disruptions in the educational provision due to the COVID-19 have affected more than 220 million students in higher education worldwide (2021).

The rapid digitalization challenges to higher education were turned into opportunities. The pandemic's impact on higher education systems must be assessed in terms of accessibility, equity, quality of learning and teaching, university functioning, national challenges, current issues, and strategic issues (Van Dinther et al., 2011; Mishra et al., 2020). Before the pandemic, the innovation rate of technology and tools in higher education in OECD countries was $49.9 \%$ (OECD, 2022). Consequently, during the pandemic, online education shares significantly increased (Armstrong et al., 2011; Harasim, 2000). Accordingly, the development of distance forms of specialists' training was ensured. The hybrid model has become a more widespread training practice. This article aims to evaluate the practice and experience in the development of distance forms of education in the context of the COVID-19 spread (Gilat \& Cole, 2020; Widana et al., 2021).

\section{Literature review}

Studies of psychological well-being found varying anxiety levels among students due to the spread of coronavirus disease, highlighting a lack of commitment to distance learning due to the professional training and learning difficulties of clinical material (Peloso et al., 2020). Lack of direct interaction also negatively impacted the desire to study remotely (Verawardina et al., 2020; Petronzi \& Petronzi, 2020).

The literature also suggests that feelings of efficacy and satisfaction contribute to students' commitment to distance learning methods (Cicha et al., 2021; Markova et al., 2017). For students to adopt distance learning models, it is important to ensure that technology is easy to use and should be useful in online training. In doing so, a sense of satisfaction contributes to student self-efficacy (Rizun \& Strzelecki, 2020).

Separate research issues are basic skills challenges; digital challenges due to the availability of technology; teaching and learning challenges; strategic and managerial challenges for the university during a pandemic (Mouchantaf, 2020; Irfan et al., 2020; Arora \& Srinivasan, 2020; Ramírez-Hurtado et al., 2021; Cicha et al., 2021). HEIs technological readiness, quality of information presentation, educator and student support, HEIs institutional readiness, and computer literacy define some of the most significant distance education components in a pandemic environment (Joaquin et al., 2020; Arshad et al., 2020; Blankenberger \& Williams, 2020; Paudel, 2021; Shahzad et al., 2021).

Consequently, on the ICT accessibility issues for distance learning provision, Agormedah et al. (2020), found a positive response from students to online learning based on UCC Moodle, Alison, and Google Classroom platforms and a desire to use social networking platforms. However, researchers found negative reactions to online learning for lack of sufficient preparation, lack of formal orientation to learning materials (Diachenko et al., 2021). Bilgic \& Tuzun (2020), found the following problems of distance education in Turkey: (1) problems of program start-up processes, (2) legislative problems. According to the UNESCO (2021) report, the pandemic has affected higher education systems in the following dimensions:

- Access: the spread of the pandemic through COVID-19 affected student enrollment, especially those whose enrollment depended on income levels and the HEIs location. High-income countries (Europe, North America) are more likely to overcome the negative effects of enrollment through government support, increasing domestic enrolment; 
- International mobility: significantly reduced international due to reduced flows of international students, despite virtual mobility, which partially offset the performance;

- University staff: the impact of the coronavirus on HEIs staff was limited, but employees needed increasing digital literacy and support;

- Research activities disruption: as a result of COVID-19, teaching research activities were suspended and canceled;

- Increased inequality: increased inequality in higher education due to escalating financial issues;

- University operations: reduced service levels and campus closures due to the spread of the virus;

- National challenges: the need to adapt, particularly digitally, to new learning environments, new regimes, strategies, models, and teaching methods, which has been a major challenge for faculty and students;

- The transition from higher education to employment: The decline in employment opportunities made it difficult for students;

- National priorities: priorities shifted strategically across countries because of the need to develop digital infrastructure.

\section{Materials and Methods}

This study uses secondary data from the UK Student Survey (Office of National Statistic COVID-19 Insights Survey (SCIS) to assess:

- Pandemic impact tendencies on their success;

- The academic situation (distance education development) and student achievements compared to the 2020-2021 academic year.

1,157 students from different UK HEIs took part in the survey. The survey was conducted between May 4-12 and November 19-29, 2021, and provides an analysis of the distance education forms, the possibility of continuing education, the reasons for students for not continuing education, the acceptability of distance education methods by students (Rovai, 2003; Boling et al., 2012; Kadir et al., 2021).

\section{Results and Discussions}

\subsection{Results}

Synchronous and asynchronous learning styles are being developed in major universities around the world during the Coronavirus spread time. At the HEIs level, the leadership provides flexible, inclusive, personalized learning through a list of learning technologies offered to faculty according to the class type (lecture, seminar, group, and individual work). Students have the option of synchronous or asynchronous viewing of learning materials. Teachers are given the opportunity, thanks to a list of technologies, to quickly generate electronic quality material.

The development of distance education depended on the restrictions imposed by the governments of different countries on the operation of HEIs (Figure 1). Countries reacted differently to the virus spread, but in general, HEIs were closed within three months, which defined a new training environment and forced a switch to distance learning methods (Howell et al., 2004; Harper et al., 2004). The average HEIs closing time was 103 days with a significant deviation in different countries - 50.4 days. The maximum closing time was in Slovenia - 216 days, and the minimum in Estonia - 39 days. Also well-known is the distance learning period implemented in Austria - 198 days, Ireland - 192 days, Belgium - 191 days, Spain - 168 days, Latvia - 167 days. Partial HEIs closure was implemented in the Czech Republic - 112 days, France - 98 days, Italy - 42.6 days, Lithuania - 35 days, the Netherlands - 78 days, Poland - 98 days, Portugal - 112 days, Slovenia - 8 days.

Voitovska, O., Kovalova, K., Kuleshova, V., Kravchuk, O., \& Moroz, O. (2022). Distance learning development in COVID-19 context. International Journal of Health Sciences, 6(1), 187-195. https://doi.org/10.53730/ijhs.v6n1.3711 


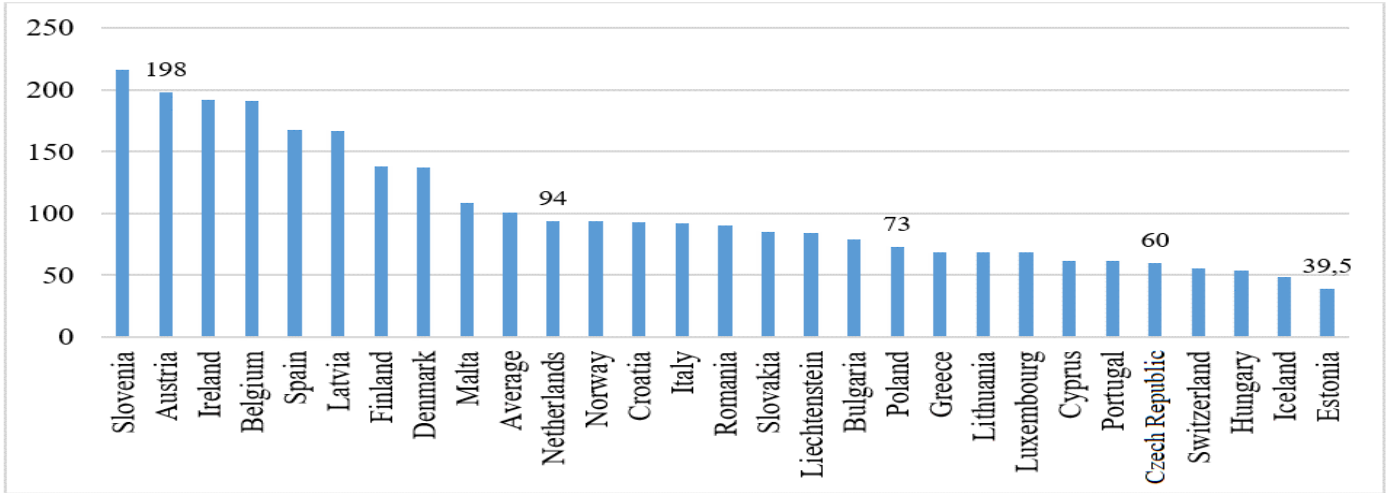

Figure 1. Closure of educational institutions (higher education) in EU during a pandemic Source: European Center for Disease Prevention. Data on country response measures to COVID-19

During the pandemic, the most common study form was online self-study or online learning with a tutor or lecturer, as reported by $55 \%$ of students. In second place was desk-based learning (self-study or online learning with a tutor or lecturer), cited by $33 \%$ of UK students surveyed. Classroom-based learning was less common, cited by only $5 \%$ of students, such as learning in lecture halls, classrooms, or on-campus labs. $7 \%$ of students indicated the prevalence of school, hospital, office, or factory-based locations. Significant changes in the development of distance education during the pandemic should also be noted. While between May 4-12, $2021,77 \%$ of students reported the prevalence of online learning or online with a tutor or lecturer, only $14 \%$ reported online learning, between November 19-29, 2021, the prevalence of online learning rose to 55\%.

Overall, $92 \%$ of students were most likely to continue their studies, $5 \%$ were undecided, and $2 \%$ were likely not to continue their studies under these conditions (Figure 2). At the same time, in the early stage of the virus, the number of those willing to continue studying was lower - $88 \%$, while the number of those unwilling to continue learning was higher (8\%). The most important reasons for not wanting to continue were: financial difficulties ( $40 \%$ of respondents who answered "unlikely" or "extremely unlikely"), physical or mental illness (32\%), online learning (28\%), limited social activities $(25 \%)$, university life not what I expected $(26 \%)$, graduation or already graduated $(28 \%)$, responsibilities outside of studies $(24 \%)$, support available from university $(26 \%)$.

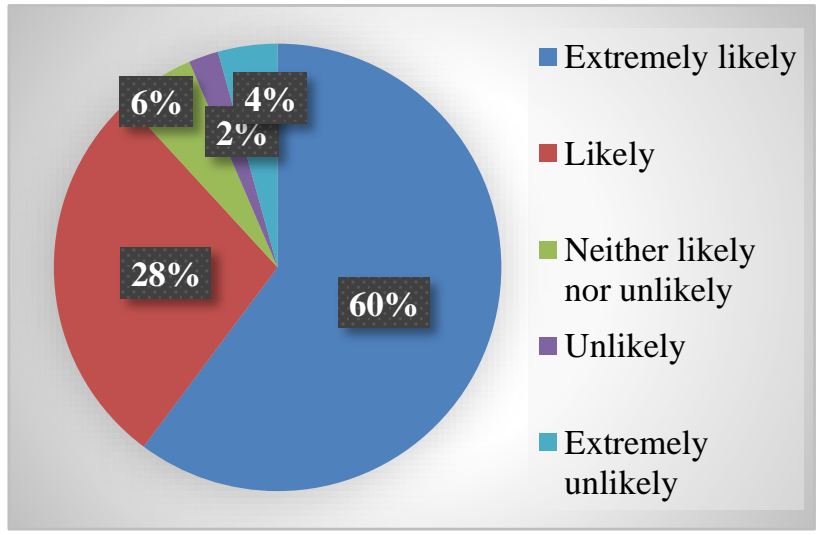

a) 4-12 May

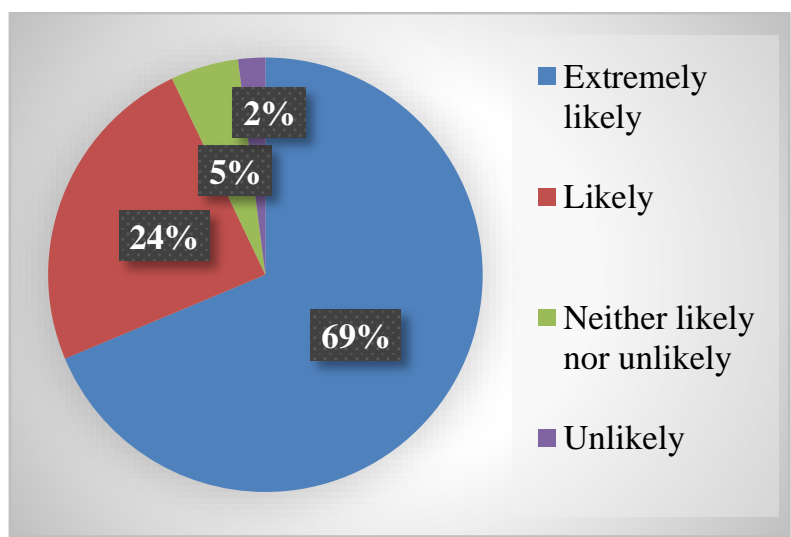

b) 19-29 November

Figure 2. How likely or unlikely are you to continue your studies this academic year?

Source: Office of National Statistic. COVID-19 Insights Survey (SCIS)

The prevalence and frequency of various distance learning methods usage have also changed over time. For example, there has been a decrease in pre-defined activities (from $34 \%$ to 30\%), an increase in access to learning materials (from 62\% to 66\%), a decrease in group work (from $29 \%$ to 18\%), a decrease in distance 
exams (from 26\% to 16\%), a decrease in pre-recorded lectures or content (from 51\% to 31\%), and a decrease in scheduled online classes from $76 \%$ to $40 \%$.

Table 1

To what extent, each of the following distance learning methods has been adopted by your University since the start of the Autumn 2021 term? \%

\begin{tabular}{lccc}
\hline \multirow{2}{*}{ Method } & \multicolumn{2}{c}{ May 4-12 } & \multicolumn{2}{c}{ November 19-29 } \\
\cline { 2 - 4 } & $\begin{array}{c}\text { Always or } \\
\text { most of the } \\
\text { time }\end{array}$ & $\begin{array}{c}\text { No time } \\
\text { most of the } \\
\text { time }\end{array}$ & No time \\
\hline $\begin{array}{c}\text { Pre-set activities (for example forum posts) by a } \\
\text { teacher with marking and feedback }\end{array}$ & $34 \%$ & $30 \%$ & $70 \%$ \\
$\begin{array}{c}\text { Making materials available for students to access } \\
\quad \text { through a website or email }\end{array}$ & $62 \%$ & $66 \%$ & $34 \%$ \\
$\begin{array}{l}\text { Online group working } \\
\text { 24-hour remote exams }\end{array}$ & $29 \%$ & $18 \%$ & $82 \%$ \\
$\begin{array}{l}\text { Pre-recorded lectures or other content } \\
\text { Scheduled live online lessons or lectures }\end{array}$ & $51 \%$ & $16 \%$ & $84 \%$ \\
\hline
\end{tabular}

Source: Office of National Statistic. COVID-19 Insights Survey (SCIS)

Thus, the change in distance learning methods may be primarily due to the removal or relaxation of restrictions during the pandemic or the digitalization of learning materials (Figure 3). Students interviewed on May 4-12 indicated a significant or strong impact of the pandemic on success: the overall proportion was $59 \%$, which is more than compared to the period November $19-29(50 \%)$.

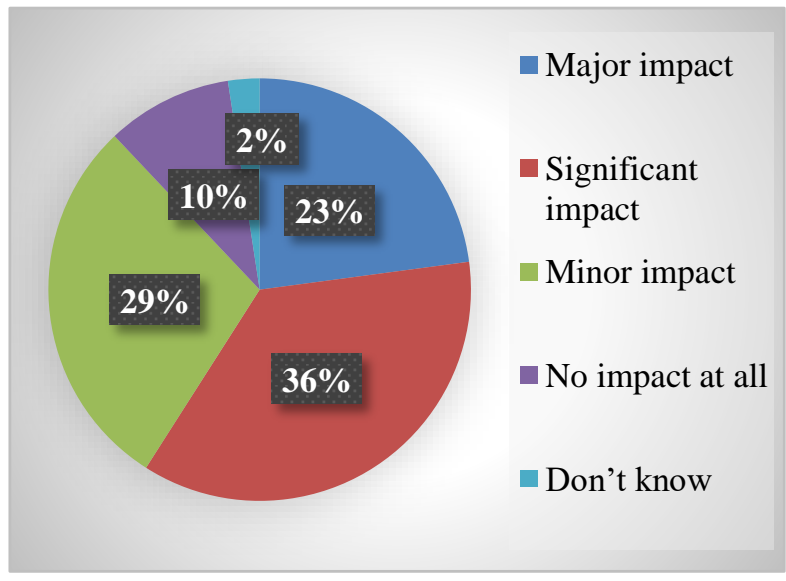

a) 4-12 May

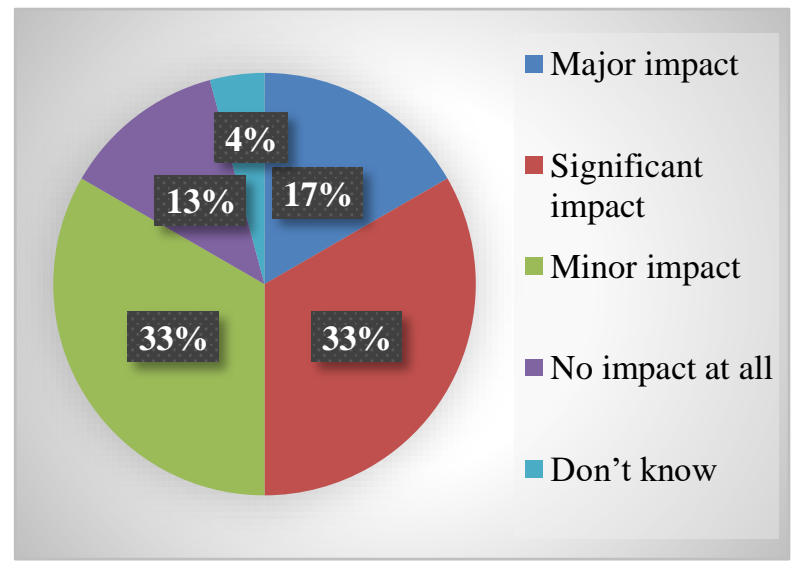

b) 19-29 November

Figure 3. How do you feel your academic performance has been impacted since the outbreak of the coronavirus (COVID-19) pandemic?

Source: Office of National Statistic. COVID-19 Insights Survey (SCIS)

A small impact on the performance during the pandemic was reported by $29 \%$ during May $4-12$ and $33 \%$ during November 19-29. No impact was reported by 10\% during May 4-12 and 13\% during November 19-29.

\subsection{Discussions}

In all academic discussions, only a few studies have evaluated students' perceptions or feelings about new distance learning methods (McRoy et al., 2020). Peloso et al. (2020), conducted a survey to assess healthrelated anxiety among tertiary. Students indicated the presence of anxiety due to the spread of the virus. As in

Voitovska, O., Kovalova, K., Kuleshova, V., Kravchuk, O., \& Moroz, O. (2022). Distance learning development in COVID-19 context. International Journal of Health Sciences, 6(1), 187-195. https://doi.org/10.53730/ijhs.v6n1.3711 
this study, it was found that the students' majority agreed with the possibility of continuing their education through distance learning. However, there was found a high level of dissatisfaction with online education. In addition, students were concerned about the difficulty of learning clinical material and professional training and the negative impact of the pandemic on learning outcomes $(70 \%)$. This study found a reduction in the pandemic negative impact level on academic performance: as measured by students from $59 \%$ to $50 \%$.

An article on the assessment of distance learning by students in Poland revealed the importance of selfefficacy, the satisfaction of using technology, the usefulness obtained, and the ease of use were found to be predictors of educational effectiveness during the pandemic (Cicha et al., 2021; Halapiry et al., 2020). The comfort of distance education by not having to travel to HEIs ensured student satisfaction.

Agormedah et al. (2020), found low student knowledge levels about online platforms and, therefore, negative student perceptions of the platforms that prevented the transition to emergency distance education during the COVID-19 pandemic. At the same time, most HEIs ensured the transition from traditional to online courses. It may be the reason for the decline in academic performance or the reason why students noted a significant impact of the pandemic on their academic performance in this study (Graham et al., 2013).

The spread of the pandemic indicates that it is not possible to replace suddenly traditional learning strategies with online classes. Although online learning practices are significantly prevalent, many HEIs and teachers have not been prepared for the full transition (Peloso et al., 2020). In particular, this is due to the need to set up and organize distance learning processes and access to online platforms for classes. Despite the lack of plans for a rapid transition to online platforms, such platforms were instantly updated to provide distance learning, complex problems, and e-learning procedure factors during this epidemic.

\section{Conclusion}

The study found that the limitations of higher education due to the spread of the coronavirus have driven the need for online education. In the UK, the most common learning form was self-study or distance learning with a lecturer/teacher, the prevalence of which has decreased with the continuation of the restrictions due to the development of forms of online learning (from 14\% to 55\%). With the development of events, the number of students who want to continue learning in crisis, which may be related to the adaptation to the new educational environment, is increasing. Financial difficulties and physical or mental illness were the most common problems that led to a reluctance to study further. In the UK, there is also a changing mix of different dissident learning methods, and the availability of online materials is on the rise. Negatively, the amount of student group work, the number of pre-recorded lectures or content, and the amount in scheduled online classes are decreasing from $76 \%$ to $40 \%$. Over time, the crisis impact level on success decreases, which is associated with the adaptation of students to the new learning environment. Further research is advisable to focus on assessing and analyzing the impact of the pandemic on the mental health of students, in particular, its relationship with the desire to learn further and academic performance.

\section{Acknowledgments}

We are grateful to two anonymous reviewers for their valuable comments on the earlier version of this paper. 


\section{References}

Agormedah, E. K., Henaku, E. A., Ayite, D. M. K., \& Ansah, E. A. (2020). Online learning in higher education during COVID-19 pandemic: A case of Ghana. Journal of Educational Technology and Online Learning, 3(3), 183-210.

Armstrong, A. W., Idriss, N. Z., \& Kim, R. H. (2011). Effects of video-based, online education on behavioral and knowledge outcomes in sunscreen use: a randomized controlled trial. Patient education and counseling, 83(2), 273-277. https://doi.org/10.1016/j.pec.2010.04.033

Arora, A. K., \& Srinivasan, R. (2020). Impact of pandemic COVID-19 on the teaching-learning process: A study of higher education teachers. Prabandhan: Indian journal of management, 13(4), 43-56.

Arshad, M., Almufarreh, A., Noaman, K. M., \& Saeed, M. N. (2020). Academic semester activities by learning management system during COVID-19 pandemic: a case of Jazan University. International Journal on Emerging Technologies, 11(5), 213-219.

Bilgiç, H. G., \& Tuzun, H. (2020). Issues and challenges with web-based distance education programs in Turkish higher education institutes. Turkish Online Journal of Distance Education, 21(1), 143-164.

Blankenberger, B., \& Williams, A. M. (2020). COVID and the impact on higher education: The essential role of integrity and accountability. Administrative Theory \& Praxis, 42(3), 404-423.

Boling, E. C., Hough, M., Krinsky, H., Saleem, H., \& Stevens, M. (2012). Cutting the distance in distance education: Perspectives on what promotes positive, online learning experiences. The Internet and Higher Education, 15(2), 118-126. https://doi.org/10.1016/j.iheduc.2011.11.006

Cicha, K., Rizun, M., Rutecka, P., \& Strzelecki, A. (2021). COVID-19 and higher education: First-year students' expectations toward distance learning. Sustainability, 13(4), 1889.

Diachenko, A., Vusyk, H., Bielova, Y., Shurdenko, M., \& Titenko, O. (2021). The educational role in COVID-19 terms of ethnodesign graphic function in higher education practical activities. International Journal of Health Sciences, 5(3), 584-593. https://doi.org/10.53730/ijhs.v5n3.2540

Gilat, R., \& Cole, B. J. (2020). COVID-19, medicine, and sports. Arthroscopy, sports medicine, and rehabilitation, 2(3), e175-e176. https://doi.org/10.1016/j.asmr.2020.04.003

Goudeau, S., Sanrey, C., Stanczak, A., Manstead, A., \& Darnon, C. (2021). Why lockdown and distance learning during the COVID-19 pandemic are likely to increase the social class achievement gap. Nature human behaviour, 5(10), 1273-1281.

Graham, C. R., Woodfield, W., \& Harrison, J. B. (2013). A framework for institutional adoption and implementation of blended learning in higher education. The internet and higher education, 18, 4-14. https://doi.org/10.1016/j.iheduc.2012.09.003

Halapiry, J., Ramadany, S., Sanusi B, Y., Made, S., Stang, S., \& Syarif, S. (2020). Children's midwifery learning media application about early detection of android-based growth in improving midwifery students skills. International Journal of Health \& Medical Sciences, 3(1), 153-159.

Harasim, L. (2000). Shift happens: Online education as a new paradigm in learning. The Internet and higher education, 3(1-2), 41-61. https://doi.org/10.1016/S1096-7516(00)00032-4

Harper, K. C., Chen, K., \& Yen, D. C. (2004). Distance learning, virtual classrooms, and teaching pedagogy in the $\begin{array}{llll}\text { Internet environment. Technology in } & \text { Society, 26(4), }\end{array}$ https://doi.org/10.1016/j.techsoc.2004.08.002

Howell, S. L., Saba, F., Lindsay, N. K., \& Williams, P. B. (2004). Seven strategies for enabling faculty success in distance education. The Internet and Higher Education, 7(1), 33-49. https://doi.org/10.1016/j.iheduc.2003.11.005

Irfan, M., Kusumaningrum, B., Yulia, Y., \& Widodo, S. A. (2020). Challenges during the pandemic: use of elearning in mathematics learning in higher education. Infinity Journal, 9(2), 147-158.

Joaquin, J. J. B., Biana, H. T., \& Dacela, M. A. (2020). The Philippine higher education sector in the time of COVID-19. In Frontiers in Education (p. 208). Frontiers.

Kadir, Y. R., Syarif, S., Arsyad, M. A., Baso, Y. S., \& Usman, A. N. (2021). Female's reproductive health application design on the school teacher knowledge: an android-based learning media. International Journal of Health \& Medical Sciences, 4(2), 189-195.

Lytvyn, V., Akimova, O., Kuznetsova, H., Zenchenko, T., Stepanenko, O., \& Koreneva, I. (2021). The use of synchronous and asynchronous teaching methods in pedagogical education in COVID-19 terms. International Journal of Health Sciences, 5(3), 617-629. https://doi.org/10.53730/ijhs.v5n3.2681

Voitovska, O., Kovalova, K., Kuleshova, V., Kravchuk, O., \& Moroz, O. (2022). Distance learning development in COVID-19 context. International Journal of Health Sciences, 6(1), 187-195. https://doi.org/10.53730/ijhs.v6n1.3711 
Markova, T., Glazkova, I., \& Zaborova, E. (2017). Quality issues of online distance learning. Procedia-Social and Behavioral Sciences, 237, 685-691. https://doi.org/10.1016/j.sbspro.2017.02.043

McRoy, C., Patel, L., Gaddam, D. S., Rothenberg, S., Herring, A., Hamm, J., ... \& Awan, O. (2020). Radiology education in the time of COVID-19: a novel distance learning workstation experience for residents. Academic radiology, 27(10), 1467-1474. https://doi.org/10.1016/j.acra.2020.08.001

Mishra, L., Gupta, T., \& Shree, A. (2020). Online teaching-learning in higher education during lockdown period of COVID-19 pandemic. International Journal of Educational Research Open, 1, 100012. https://doi.org/10.1016/j.iheduc.2012.09.003

Mouchantaf, M. (2020). The COVID-19 pandemic: Challenges faced and lessons learned regarding distance learning in Lebanese higher education institutions. Theory and Practice in Language Studies, 10(10), 12591266.

OECD (2022). Comparing innovation in education with other sectors.

Paudel, P. (2021). Online education: Benefits, challenges and strategies during and after COVID-19 in higher education. International Journal on Studies in Education, 3(2), 70-85.

Peloso, R. M., Ferruzzi, F., Mori, A. A., Camacho, D. P., Franzin, L. C. D. S., Margioto Teston, A. P., \& Freitas, K. M. S. (2020). Notes from the field: concerns of health-related higher education students in Brazil pertaining to distance learning during the coronavirus pandemic. Evaluation \& the Health Professions, 43(3), 201-203.

Petronzi, R., \& Petronzi, D. (2020). The Online and Campus (OaC) Model as a Sustainable Blended Approach to Teaching and Learning in Higher Education: A Response to COVID-19. Journal of Pedagogical Research, 4(4), 498-507.

Ramírez-Hurtado, J. M., Hernández-Díaz, A. G., López-Sánchez, A. D., \& Pérez-León, V. E. (2021). Measuring online teaching service quality in higher education in the covid-19 environment. International Journal of Environmental Research and Public Health, 18(5), 2403.

Rizun, M., \& Strzelecki, A. (2020). Students' acceptance of the Covid-19 impact on shifting higher education to distance learning in Poland. International Journal of Environmental Research and Public Health, 17(18), 6468.

Rovai, A. P. (2003). In search of higher persistence rates in distance education online programs. The internet and higher education, 6(1), 1-16. https://doi.org/10.1016/S1096-7516(02)00158-6

Schneider, S. L., \& Council, M. L. (2021). Distance learning in the era of COVID-19. Archives of dermatological research, 313(5), 389-390.

Shahzad, A., Hassan, R., Aremu, A. Y., Hussain, A., \& Lodhi, R. N. (2021). Effects of COVID-19 in E-learning on higher education institution students: the group comparison between male and female. Quality \& quantity, 55(3), 805-826.

UNESCO (2021). New UNESCO global survey reveals impact of COVID-19 on higher education.

Van Dinther, M., Dochy, F., \& Segers, M. (2011). Factors affecting students' self-efficacy in higher education. Educational research review, 6(2), 95-108. https://doi.org/10.1016/j.edurev.2010.10.003

Verawardina, U., Asnur, L., Lubis, A. L., Hendriyani, Y., Ramadhani, D., Dewi, I. P., ... \& Sriwahyuni, T. (2020). Reviewing online learning facing the Covid-19 outbreak.Journal of Talent Development and Excellence, 12(3s), 385-392.

Widana, I.K., Sumetri, N.W., Sutapa, I.K., Suryasa, W. (2021). Anthropometric measures for better cardiovascular and musculoskeletal health. Computer Applications in Engineering Education, 29(3), 550561. https://doi.org/10.1002/cae.22202 


\section{Biography of Authors}

\begin{tabular}{|c|c|}
\hline 16 & $\begin{array}{l}\text { Oksana Voitovska } \\
\text { Doctor in Education, Associate Professor of the Department of Pedagogy and } \\
\text { Psychology of Preschool Education and Childrens Creativity, Faculty of Pedagogy } \\
\text { and Psychology, National Pedagogical Dragomanov University, Kyiv, Ukraine } \\
\text { ORCID identifier: 0000-0002-1814-5895 } \\
\text { Email: ovoitovskaya@ukr.net }\end{array}$ \\
\hline & $\begin{array}{l}\text { Kaleriia Kovalova } \\
\text { PhD in Philology, Associate Professor, Faculty of Foreign Citizens Training, } \\
\text { Department of Foreign Languages and Cross-Cultural Communication, Simon } \\
\text { Kuznets Kharkiv National University of Economics, Kharkiv, Ukraine } \\
\text { ORCID identifier: 0000-0001-6718-8034 } \\
\text { Email: valeriykovaleva@gmail.com }\end{array}$ \\
\hline & $\begin{array}{l}\text { Viktoriia Kuleshova } \\
\text { Doctor of Pedagogical Sciences, Head of the department, Department of } \\
\text { Educational Technologies and Labor Protection, Educational-Scientific } \\
\text { Professional-Pedagogical Institute of Ukrainian Engineering Pedagogics Academy, } \\
\text { Ukraine } \\
\text { Email: vika12rada@gmail.com }\end{array}$ \\
\hline & $\begin{array}{l}\text { Oksana Kravchuk } \\
\text { Doctor of Pedagogical Sciences, Professor of the Department of Professional } \\
\text { Methods and Innovative Technologies in Primary School, Pavlo Tychyna Uman } \\
\text { State Pedagogical University, Uman, Ukraine } \\
\text { ORCID identifier: 0000-0001-6502-5856 } \\
\text { E-mail: o.v.kravchuk@udpu.edu.ua }\end{array}$ \\
\hline & $\begin{array}{l}\text { Olena Moroz } \\
\text { Candidate of Philological Sciences, Associate Professor of the English Language } \\
\text { Department for Deck Officers, Navigation faculty, English Language Department } \\
\text { for Deck Officers, Kherson State Maritime Academy, Kherson, Ukraine } \\
\text { ORCID identifier: 0000-0002-1483-9136 } \\
\text { Email: alyona_moroz@ukr.net }\end{array}$ \\
\hline
\end{tabular}

Voitovska, O., Kovalova, K., Kuleshova, V., Kravchuk, O., \& Moroz, O. (2022). Distance learning development in COVID-19 context. International Journal of Health Sciences, 6(1), 187-195. https://doi.org/10.53730/ijhs.v6n1.3711 